\section{A novel DAX1/NROB1 mutation in a patient with adrenal hypoplasia congenita and hypogonadotropic hypogonadism}

\author{
Uma nova mutação DAX1 / NROB1 em um paciente com hipoplasia \\ adrenal congênita e hipogonadismo hipogonadotrófico
}

Claudilene Battistin', Hamilton Cabral de Menezes Filho', Sorahia Domenice², Mirian Yumie Nishi' ${ }^{2}$, Thais Della Manna', Hilton Kuperman', Leandra Steinmetz', Vaê Dichtchekenian', Nuvarte Setian', Durval Damiani'

\section{SUMMARY}

1 Pediatric Endocrinology Unit/ LIM36, Endocrinology Department, Instituto da Criança, Hospital das Clínicas, Faculdade de Medicina da Universidade de São Paulo (ICFHC-FMUSP), São Paulo, SP, Brazil ${ }^{2}$ Developmental Endocrinology Unit, Hormone and Molecular Genetics Lab/LIM42, Endocrinology Department, ICr-HC-FMUSP, São Paulo, SP, Brazil

Correspondence to:

Durval Damiani

Instituto da Criança, Hospital das Clínicas, Faculdade de Medicina da Universidade de São Paulo Rua Cônego Eugênio Leite, 693, ap. 151

São Paulo, SP, Brazil - 05414-011 durvald@iconet.com.br

Received on June/27/2012 Accepted on Sept/10/2012
We report a case of adrenal hypoplasia congenita $(\mathrm{AHC})$ and hypogonadotropic hypogonadism $(\mathrm{HH})$ due to a novel DAX1 mutation. A 19-month-old boy with hyperpigmentation and failure to thrive came to our service for investigation. Three brothers of the patient had died due to adrenal failure, and a maternal cousin had adrenal insufficiency. Adrenoleukodystrophy was excluded. MRI showed normal pituitary and hypothalamus. Plasma hormone evaluation revealed high ACTH (up to 2,790 pg/mL), and low levels of androstenedione, DHEA-S, 11-deoxycortisol, and cortisol. At 14 years of age the patient was still prepubescent, his weight was 43.6 kg (SDS: -0.87) and his height was $161 \mathrm{~cm}$ (SDS: -0.36), with normal body proportions. In the $\mathrm{GnRH}$ test, basal and maximum values of $\mathrm{LH}$ and $\mathrm{FSH}$ were respectively $0.6 / 2.1$ and $<1.0 /<1.0$ $U / L$. Molecular investigation identified a novel mutation that consists of a deletion of codon 372 (AAC; asparagine) in exon 1 of DAX1. This mutation was not found in a study of 200 alleles from normal individuals. Prediction site analysis indicated that this alteration, located in the DAX1 ligand-binding domain, may damage DAX1 protein. We hypothesize that the novel (p.Asp372del) DAX1 mutation might be able to cause a disruption of DAX1 function, and is probably involved in the development of $\mathrm{AHC}$ and $\mathrm{HH}$ in this patient. Arq Bras Endocrinol Metab. 2012;56(8):496-500

\section{SUMÁRIO}

Relatamos um caso de hipoplasia adrenal congênita (HAC) e hipogonadismo hipogonadotrófico $(\mathrm{HH})$ causado por uma nova mutação do gene DAX1. Paciente do sexo masculino com 19 meses de idade, hiperpigmentação e desenvolvimento inadequado foi encaminhado ao nosso serviço. Antecedente familiar de três irmãos falecidos por falência da adrenal, e um primo materno portador de insuficiência adrenal. Excluída a hipótese de adrenoleucodistrofia. A RM demonstrou hipófise e hipotálamo normais. Os níveis de hormônios plasmáticos mostraram alta concentração de ACTH (até $2.790 \mathrm{pg} / \mathrm{mL}$ ) e baixos níveis de androstenediona, DHEA-S, 11-deoxicortisol e cortisol. Aos 14 anos de idade, o paciente ainda era pré-púbere, com peso de 43,6 kg (SDS: $-0,87$ ) e altura de $161 \mathrm{~cm}$ (SDS: -0,36), proporcionado. 0 teste do $\mathrm{GnRH}$ mostrou níveis basais e máximos de $\mathrm{LH}$ e FSH, respectivamente, iguais a 0,6/2,1 e $<1,0 /<1,0 \mathrm{U} / \mathrm{L}$. A análise molecular identificou uma nova mutação que consiste da deleção do códon 372 (AAC; asparagina) no éxon 1 do gene $D A X 1$. Essa mutação não foi encontrada em 200 alelos de indivíduos normais. A análise no site PredictProtein indicou que essa alteração, localizada no domínio de ligação do DAX1, pode danificar a proteína. Nossa hipótese é que essa nova mutação (p.Asp372del) do gene $D A X 1$ pode levar a uma alteração na função da proteína DAX1 e está provavelmente envolvida no desenvolvimento da HAC e HH nesse paciente. Arq Bras Endocrinol Metab. 2012;56(8):496-500 


\section{INTRODUCTION}

A drenal hypoplasia congenita (AHC) is a developmental disorder of the adrenal gland, and was first described in 1948 by Sikl. It is estimated to affect $1 / 12,500$ live newborns (1-3). Four clinical forms of AHC have been described: 1) a sporadic form, associated with hypoplasia of the pituitary gland and characterized by small adrenal glands and a reduction of the fetal zone; 2) a recessive autosomal form, with miniature adult adrenal morphology; 3) an X-linked cytomegalic form associated with hypogonadotropic hypogonadism $(\mathrm{HH})$; 4) an X-linked form associated with glycerol kinase deficiency and/or Duchenne muscular dystrophy $(3,4)$.

The X-linked cytomegalic form of AHC is characterized by hypofunctioning adrenals, absence of permanent adrenal cortex, and disorganization of the structure of the gland. These alterations cause early primary adrenal insufficiency, characterized by low serum levels of glucocorticoids, mineralocorticoids, and androgens, and failure to respond to stimulation with adrenocorticotropic hormone (ACTH). Later on, these patients are also diagnosed with $\mathrm{HH}(1,5,6)$.

The X-linked cytomegalic form of AHC is caused by inactivating mutations in $D A X I / N R O B I$ (dosage-sensitive sex reversal-adrenal hypoplasia congenita critical region on the $\mathrm{X}$ chromosome, gene $1 /$ nuclear receptor subfamily 0 , group $\mathrm{B}$, member $\mathrm{l}$ ). This gene encodes an orphan nuclear factor that, unlike other members of the nuclear receptor superfamily, does not possess a zinc-finger domain (47). $D A X I$ is located on the short arm of $\mathrm{X}$ chromosome (Xp2l), and is composed by two exons containing, respectively, 1,168 and 254 bp, separated by a 3,385-bp intron. It encodes a 470 -amino-acid protein $(4,6,8)$.

$D A X I$ plays a key role in the development of the adrenal gland, testis, ovary, pituitary gland, and hypothalamus (3). DAXI expression colocalizes with that of SFl (steroidogenic factor 1), however not in all tissues. $D A X 1$-positive, SFl-negative cells are found in embryonic mouse testis, postnatal ovary, and most notably, in developing pituitary and hypothalamus, which suggests a function for $D A X I$ that is independent of SFI. However, how disruption of $D A X I$ leads to adrenal, hypothalamic, and pituitary developmental defects similar to SFI disruption, still remains to be clarified (9).

Classically, DAXI mutations have been identified in males with primary adrenal insufficiency and $\mathrm{HH}$. However, a wide range of phenotypes have been described in the literature (10).

This article describes a case of AHC associated with $\mathrm{HH}$ due to a novel $D A X I$ mutation.

\section{CASE REPORT}

The male patient was first evaluated when he was 19 months old. He was born from non-consanguineous and healthy parents by vaginal delivery, after an uneventful pregnancy. His birth weight and birth length were respectively $3,080 \mathrm{~g}$ (SDS: 0 ) and $50 \mathrm{~cm}$ (SDS: -0.79). Maternal menarche was at 11 years old, and she had nine pregnancies and three miscarriages. Three brothers ha died (at 26, 23 and 11 months) from dehydration and probable adrenal insufficiency, two sisters had died from prematurity, and a maternal cousin had adrenal insufficiency. The patient was admitted to the Pediatric Endocrinology outpatient clinic due to failure to thrive, darkening of the skin, and excessive thirst during the previous 5 months. At physical exam he was pale, his weight was $9.7 \mathrm{~kg}$ (SDS: - 1.92) and his height was $80.5 \mathrm{~cm}$ (SDS: -0.74). Laboratory tests were compatible with a diagnosis of primary adrenal insufficiency: ACTH up to $2,790 \mathrm{pg} / \mathrm{mL}$ (normal range: up to $46 \mathrm{pg} / \mathrm{mL}$ ), cortisol $=0.2 \mu \mathrm{g} / \mathrm{dL}$ (normal range: 5.4 to $25 \mu \mathrm{g} / \mathrm{dL}$ ). Plasma concentrations of other adrenocortical hormones were notably low: androstenedione $=0.3 \mathrm{ng} / \mathrm{mL}$ (normal range: 0.3 to $3.3 \mathrm{ng} / \mathrm{mL}$ ), dehydroepiandrosterone sulfate $<20 \mathrm{ng} / \mathrm{mL}$ (normal range: up to $194 \mathrm{ng} / \mathrm{mL}$ ), 11-deoxycortisol < $0.4 \mathrm{ng} /$ $\mathrm{mL}$ (normal range: 2.5 to $4.0 \mathrm{ng} / \mathrm{mL}$ ). Laboratory evaluation ruled out adrenoleukodystrophy (normal plasma concentration of very long-chain fatty acids) and glycerol kinase deficiency. Radiological evaluation (adrenal ultrasonography and brain MRI) was normal.

The patient was treated with glucocorticoid and $9 \alpha-$ fluodrocortisone, with dosages adjusted during followup. However, adherence to treatment was not satisfactory, so the patient experienced several episodes of acute adrenal insufficiency followed by seizures. At these moments, electrolyte plasma concentrations confirmed mineralocorticoid insufficiency: sodium $=123 \mathrm{mEq} / \mathrm{L}$ (normal range: 135 to $147 \mathrm{mEq} / \mathrm{L}$ ), and potassium $=$ $6.0 \mathrm{mEq} / \mathrm{L}$ (normal range: 3.6 to $4.8 \mathrm{mEq} / \mathrm{L}$ ). These episodes were treated with intravenous hydrocortisone and blood volume replacement. Table 1 shows the hormonal and electrolytic profile of the patient.

During his follow-up, cryptorchidism was found on the right side. The testicle was palpable in the inguinal canal. A human chorionic gonadotropin (hCG) stimulation test ( single dose of $3,000 \mathrm{U} / \mathrm{m}^{2}$ ) suggested compromised testicular function (testosterone after hCG = $14 \mathrm{ng} / \mathrm{dL}$ ). The patient was subjected to orchidopexy at the age of 10 . 
Clinical evaluation at 14 years old identified absent pubertal signs (Tanner stage PlGl, testicular volume $=2 \mathrm{~mL}$, bilaterally). At this time, the patient reached weight of $43.6 \mathrm{~kg}$ (SDS: -0.87) height of $161 \mathrm{~cm}$ (SDS:

Table 1. Hormonal and electrolytic profile during follow-up

\begin{tabular}{lccc}
\hline Age (months) & ACTH $\mathbf{( p g / m L})$ & DHEA (ng/mL) & $\mathbf{N a / K ~ ( m E q / L ) ~}$ \\
\hline 30 & - & 0.5 & $123 / 6.0$ \\
70 & 328 & - & $142 / 4.4$ \\
147 & - & - & $128 / 5.5$ \\
157 & 2,790 & $<0.1$ & $140 / 4.2$ \\
165 & 1,160 & - & $140 / 4.6$ \\
\hline
\end{tabular}

ACTH: adrenocorticotropic hormone; DHEA: dehydroepiandrosterone;

Na: sodium; K: potassium.

-0.36), and exhibited hyperpigmentation of the oral cavity (Figure 1). Response to stimulation with gonadotropin-releasing hormone (GnRH) was decreased, and bone age was delayed (12.5 years, SDS:-1.54).

A sample of the patient's peripheral blood was collected for molecular analysis after informed consent was provided.

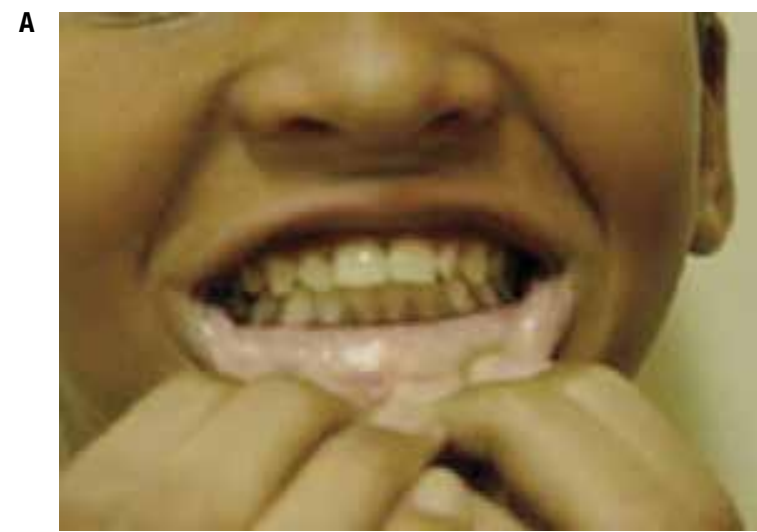

B

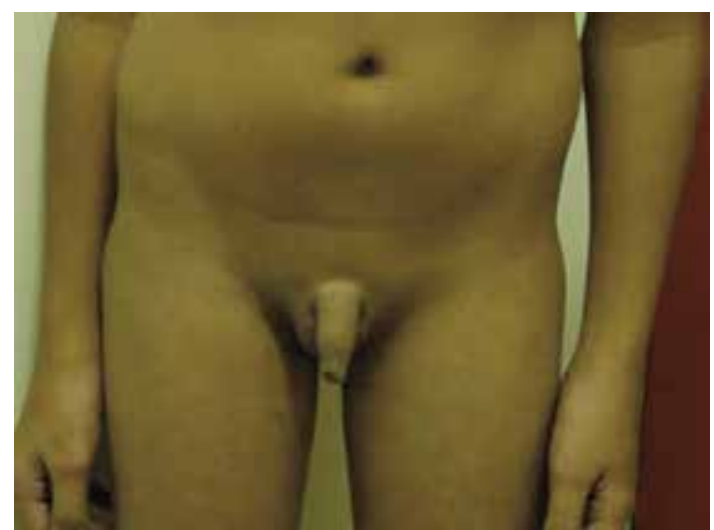

Figure 1. Clinical features of the patient at 14 years of age. Note the hyperpigmentation of the oral mucosa $(\mathbf{A})$ and the pre-pubescent appearance (B).

\section{Molecular analysis and results}

Genomic DNA was isolated from peripheral blood leukocytes of the patient. Both exons of DAXI/NROBIA (ENSG00000169297) and the intronic flanking sequences were amplified by polymerase chain reaction using specific primers and conditions, as described elsewhere (11). The amplicons were submitted to enzymatic purification with ExoSAP-IT kit (GE Healthcare Life Sciences, CT, USA), and directly sequenced using BigDye ${ }^{\mathrm{TM}}$ Terminator Cycle Sequencing Ready Reaction Kit (Life Technologies, CA, USA) in an ABI PRISM 3100 automatic sequencer. Samples from 100 controls were also analyzed.

An allelic variant of $D A X I / N R O B I A$ was identified and its functional effects were predicted, in silico, using PolyPhen, SIFT, and PredictProtein software (12-14).

The sequencing of DAXI/NROBIA identified the allelic variant c.1114_1116delAAC (p.Asp372del) in exon 1 (Figure 2 ). This variant was not identified in a study of 200 alleles from normal individuals. Adapted analysis of this DAXI variant protein using PolyPhen and SIFT programs indicated that this alteration may damage the protein.

PredictProtein analysis suggested that the deletion of the amino acid (Asp) changed the secondary structure of the protein by eliminating a loop in this region (14). In the wild-type DAXl protein, this

A
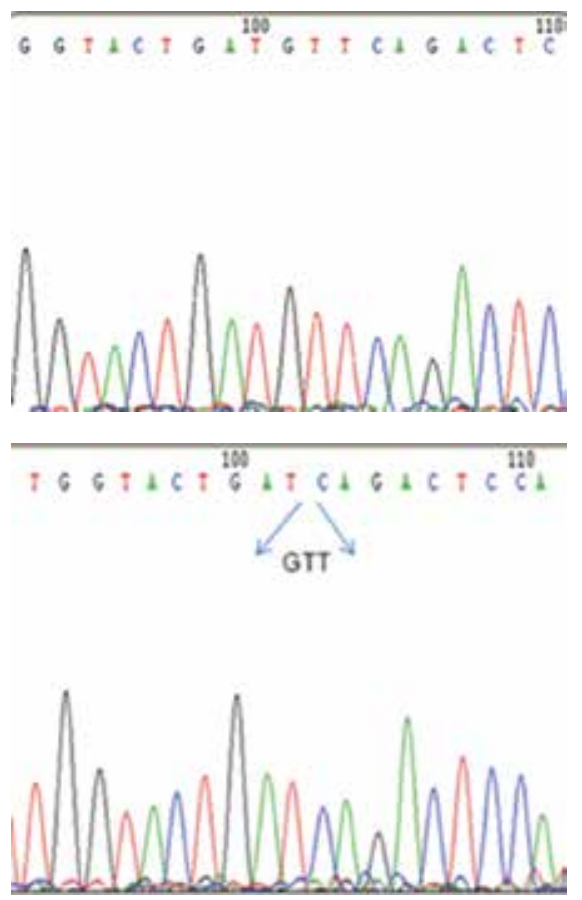

Figure 2. Electropherograms of the reverse sequence of $D A X 1 / N R O B 1 A$ exon 1 in $\mathbf{( A )}$ a control and (B) the index case. Deletion of three nucleotides (AAC) at position 1114-1116 leads to the loss of the amino acid asparagine at position 372. 
loop consists of three amino acids (asparagine, isoleucine, serine) beginning at Asp372. In the absence of asparagine, the loop disappears.

\section{DISCUSSION}

Inactivating $D A X I$ mutations are well-established etiologies of the association between $\mathrm{X}$-linked $\mathrm{AHC}$ and $\mathrm{HH}$ (OMIM:300200) (15). Deletions and point mutations within the $D A X 1$ gene have been described in more than 70 families exhibiting AHC $(7,16)$. The prevalence of inactivating $D A X 1$ mutations in the male population is estimated at $1: 70,000$ to $1: 600,000(17,18)$.

$D A X I$ is expressed in the adrenal gland, gonads, hypothalamus, and pituitary gonadotropes $(3,8,15,17)$, and plays a significant role at several levels of the function and development of the reproductive axis (15). $\mathrm{HH}$ in patients with DAXI mutations involves deficiencies at both hypothalamic and pituitary levels. Sertoli cells also express the DAXI gene, and $D A X 1-/$ rats exhibit reduced spermatogenesis and fertility (6).

In most male patients with DAXI inactivation, AHC is manifested in infancy and childhood by means of episodes of salt loss characterized by vomiting, diarrhea, dehydration, hyponatremia, hyperkalemia, and hypoglycemia. These episodes are frequently triggered or aggravated by acute stress (usually an acute viral infection), and may be accompanied by seizures. Later, these patients are further characterized by delayed $\mathrm{pu}-$ berty due to $\mathrm{HH}(10,17,19)$.

In 2006, Lin and cols. described a case series including 64 male patients with primary adrenal insufficiency. The symptoms occurred before the first year of life in $79 \%$ of these patients, while $D A X 1$ mutations were identified in $59 \%$ of patients (18). In 2010, Landau and cols. described 12 patients with $D A X 1$ mutations in Israeli families and reported that clinical manifestations were noted before the age of 8 weeks in $83 \%$ of these patients (17). In Li's case series, however, signs and symptoms were noticed later, usually after the age of 2 years (19). In the patient described in this article, clinical manifestations were noticed at the age of 14 months.

The vast majority of boys with $D A X I$ mutations described in the literature evolve with delayed puberty, characterized by absence of secondary sexual characteristics beyond age $14(3,15,16,19,20,21)$. In some patients, incomplete pubertal development and a marked reduction of testicular volume have also been noted $(19,22,23) . \mathrm{Li}$ and cols. showed that the expression of $G n R H$ is increased in a dose-dependent manner by steroidogenic factor $\mathrm{l}(S F \mathrm{l})$ in individuals with normal $D A X I$; in those with $D A X I$ mutations (e.g., p.R267P, p.L262P， p.C368F， c.637delC， c.652_653delAC), there is a severe decrease in $G n R H$ expression, explaining the presence of $\mathrm{HH}$ (19).

The patient described in this article exhibited a profile compatible with delayed puberty, failing to respond to stimulation with $\mathrm{GnRH}$ at the age of 14 , which supports the hypothesis of HH. However, he had been previously subjected to right-side orchidopexy with unsatisfactory testosterone response to hCG stimulation, suggesting compromised testicular function, probably due to a lack of gonadotropic stimulation. Chronically non-stimulated testes require longer-term stimulation with higher doses of hCG in order to produce proper serum levels of testosterone. In the case described here, we performed the test with a single dose of hCG because several previous attempts to conduct 4 -week stimulation tests failed due to patient non-compliance.

Curiously, in 2001, Domenice and cols. described a male patient with a $D A X I$ mutation and early puberty with enlarged testes, but with prepubertal levels of luteinizing hormone. Treatment with a GnRH analogue did not reduce plasma levels of testosterone, which were only achieved after treatment with glucocorticoid and mineralocorticoid. Thus, this patient represents a case of ACTH-dependent early puberty in which the synthesis and secretion of testosterone by Leydig cells was stimulated by means of the activation of melanocortin receptor 1 (10). Ahmad and cols. described a similar case of a patient with AHC and bilateral increase of testicular volume, but the disorder seemed to be independent of ACTH, and treatment with glucocorticoid did not reduce testicular size (24).

Seminara and cols. described several families in which women heterozygous for DAXI mutations exhibited delayed puberty. In all cases, the most noticeable clinical manifestation was delayed menarche (average of 17 years) without associated adrenal involvement or infertility $(6,15)$. Although the molecular studies of the mother were lost, her puberty was apparently normal since her menarche occurred at 11 years of age.

It is evident that many contributions to the molecular investigation of adrenal disorders in childhood have been made over the last 15 years (18). Up to mid-2006, approximately 80 to $100 D A X 1$ mutations had been described $(8,20)$. Currently, approximately $200 D A X I$ mutations are known, including deletions involving the 
NROBI gene alone or along adjacent genes, such as the gene associated with Duchenne muscular dystrophy or glycerol kinase, in a kind of "contiguous gene syndrome" and nonsense, frameshift, or missense mutations (22). Most mutations are frameshift or nonsense substitutions that give rise to truncated proteins with significant lossof-function effects (25). A complete phenotype-genotype correlation has not been established yet.

In the case described here, a novel allelic variant of $D A X I$ was characterized by a deletion of three base pairs (AAC) from exon 1, resulting in the loss of one asparagine (codon 372). PredictProtein analysis showed that the wild-type DAXl protein contained a three-amino-acid loop at positions 372-374 (asparagine, isoleucine, serine). In the absence of Asp372, this loop disappears, causing a significant change in the secondary structure of the DAXI protein. We hypothesize that this change would disrupt the function of the $D A X 1$ protein because the missing amino acid is located in the ligand-binding domain, an important region of the protein.

In conclusion, the possibility of an inactivating $D A X 1$ mutation must be considered in all male patients with a clinical profile compatible with early-onset primary adrenal insufficiency.

The identification of $D A X I$ mutations is important for genetic counseling regarding future pregnancies, and especially for the early identification of patients at risk for episodes of acute primary adrenal insufficiency, which are associated to high morbidity and mortality.

Disclosure: no potential conflict of interest relevant to this article was reported.

\section{REFERENCES}

1. Niakan KK, McCabe ERB. DAX-1 origin, function, and novel role. Mol Genet Metab. 2005;86:70-83.

2. Sikl H. Addison's disease due to congenital hypoplasia of the adrenals in an infant aged 33 days. J Pathol Bacteriol. 1948;60:323-4.

3. SekiguchiY, HaraY, Matsuoka H, HayashiY, Katsumata N, Hirata Y. Sibling cases of Addison's disease caused by DAX-1 gene mutations. Intern Med. 2007;46(1):35-9.

4. Fujieda K, TajimaT. Molecular basis of adrenal insufficiency. Pediatr Res. 2005;57(5Pt2):62R-9R.

5. Zanaria E, Muscatelli F, Bardoni B, Strom TM, Guioll S, Guo W, et al. An unusual member of the nuclear hormone receptor superfamily responsible for $\mathrm{X}$-linked adrenal hypoplasia congenita. Nature. 1994;372:635-41.

6. Seminara SB, Achermann JC, Genel M, Jameson JL, Crowley WF Jr. X-linked adrenal hypoplasia congenita: a mutation in DAX1 expands the phenotypic spectrum in males and females. J Clin Endocrinol Metab. 1999;84(12):4501-9.

7. Mericq V, Ciaccio M, Marino R, Lamoglia JJ, Viterbo G, Rivarola MA, et al. A new DAX-1 mutation in a family with a case of neonatal adrenal insufficiency and a sibling with adrenal hypoplasia and sudden death at 3 years of age. J Pediatr Endocrinol Metab. 2007;20(9):1039-43.

8. Mantovani RM, Pezzuti IL, Dias VMA, Silva IN. Identification of a novel mutation in DAX1/NR0B1A gene in two siblings with severe clinical presentation of adrenal hypoplasia congenita. Arq Bras Endocrinol Metab. 2009;53(6):771-6.

9. Iyer AK, McCabe ERB. Molecular mechanisms of DAX1 action. Mol Genet Metab. 2004;83:60-73.

10. Domenice S, Latronico AC, Brito VN, Arnhold IJP, Kok F, Mendonca BB. Adrenocorticotropin-dependent precocious puberty of testicular origin in a boy with X-linked adrenal hypoplasia congenita due to a novel mutation in the DAX1 gene. J Clin Endocrinol Metab. 2001;86(9):4068-71.

11. Yanase T, Takayanagi R, Oba K, Nishi Y, Ohe K, Nawata H. New mutations of DAX1 genes in two Japanese patients with X-linked congenital adrenal hypoplasia and hypogonadotropic hypogonadism. J Clin Endocrinol Metab. 1996;81(2):530-5.

12. PolyPhen: prediction of functional effect of human nsSNPs. Available at: http://genetics.bwh.harvard.edu/pph/.

13. SIFT: sorts intolerant from tolerant amino acid substitutions. Available at: http://sift.bii.a-star.edu.sg/.

14. PredictProtein: protein database searches and the prediction of aspects of protein structure and function. Available at: http:// www.predictprotein.org.

15. Achermann JC, GUWX, KotlarTJ, Meeks JJ, Sabacan LP, Seminara SB, et al. Mutational analysis of DAX-1 in patients with hypogonadotropic hypogonadism or pubertal delay. J Clin Endocrinol Metab. 1999;84(12):4497-500.

16. Calvari V, Alpigiani MG, Poggi E, Podesta B, Camerino G, Lorini R. X-linked adrenal hypoplasia congenita and hypogonadotropic hypogonadism: report on new mutation of the DAX-1 gene in two siblings. J Endocrinol Invest. 2006;29(1):41-7.

17. Landau Z, Hanukoglu A, Sack J, Goldstein N, Weintrob N, Eliakim $A$, et al. Clinical and genetic heterogeneity of congenital adrenal hypoplasia due to NROB1 gene mutations. Clin Endocrinol. 2010;72(4):448-54.

18. Lin L, GuWX, Ozisik G, ToWS, Owen CJ, Jameson JL, et al. Analysis of DAX1 (NR0B1) and steroidogenic factor-1 (NR5A1) in children and adults with primary adrenal failure: ten years' experience. J Clin Encdocrinol Metab. 2006;91(8):3048-54.

19. Li Na, Liu R, Zhang H, Yang J, Sun S, Zhang M, et al. Seven novel DAX1 mutations with loss of function identified in Chinese patients with congenital adrenal hypoplasia. J Clin Endocrinol Metab. 2010;95(9):E104-11.

20. Mantovani G, De Menis E, Borretta G, Radetti G, Bondioni S, Spada A, et al. DAX1 and X-linked adrenal hypoplasia congenita: clinical and molecular analysis in five patients. Eur J Endocrinol. 2006;154(5):685-9.

21. Tsai WY, Tung YC. Novel deletion mutations of the DAX1 (NR0B1) gene in two Taiwanese families with $X$-linked adrenal hypoplasia congenita. J Clin Endocrinol Metab. 2005;18(10):991-7.

22. Malpartida KG, Balaguer MG, Izquierdo ES, Pardilla MJF, Fernán$\operatorname{dez} A J$, Ruiz IS, et al. A novel mutation in DAX1 (NROB1) causing $X$-linked adrenal hypoplasia congenita: clinical, hormonal and genetic analysis. Endocrine. 2009;36:275-80.

23. Jadhav U, Harris RM, Jameson JL. Hypogonadotropic hypogonadism in subjects with DAX1 mutations. Mol Cell Endocrinol. 2011;346:65-73.

24. Ahmad I, Paterson WF, Lin L, Adlard P, Duncan P, Tolmie J, et al. A novel missense mutation in DAX-1 with an unusual presentation of X-linked adrenal hypoplasia congenita. Horm Res. 2007;68:32-7.

25. Laissue P, Copelli S, Bergada I, Bergada C, Barrio G, Karaboga S, et al. Partial defects in transcriptional activity of two novel DAX-1 mutations in childhood-onset adrenal hypoplasia congenita. Clin Endocrinol. 2006;65(5):681-6. 